\title{
Making Bioethanol From Cocoa Fruit Skin Waste By Hydrolysis Process Using Trichoderma Viride Mold
}

\author{
Tiska Oktavianis, Sofiyanita \\ Chemical Education of the State Islamic University Sultan Syarif Kasim Riau \\ *E-mail : tiskaoktavianis@gmail.com
}

\begin{abstract}
Cocoa fruit skin is one of the agricultural wastes can be used as raw material for bioethanol production. Because the cocoa fruit waste containing $39.45 \%$ crude fiber and $3.92 \%$ glucose. The purpose of this study was to determine the level of optimization of yeast and fermentation time to produce maximum ethanol content. In this study the hydrolysis process cocoa leather is done using fungi Trichoderma viride and fermentation process using yeast Saccharomyses cerevisiae. While for bioethanol concentration measurements performed using vinometer. The results showed that bioethanol fermentation time for 1, 3, 5 and 7 days using yeast levels 2, 4, 6 and 8 grams produce maximum ethanol fermentation at 3 days and 6 grams yeast levels. Produced a maximum ethanol content of $12 \%$
\end{abstract}

Keywords: Waste Cocoa Pods, Bioethanol, Trichoderma viride and Vinometer

\section{Introduction}

At present, the community's need for fuel use is increasing. The increase in the number of people's needs for this fuel is not followed by the increase in petroleum reserves available today, so that it will cause fuel scarcity and increase the fuel cost. The method that can be taken to overcome these problems is by using alternative fuels, one of the alternative fuels that can be used is bioethanol. In addition, the use of gasoline which is one example of fuel oil can have a negative impact, such as air pollution by producing exhaust gases carbon monoxide which can damage health. When compared with the use of bioethanol, the result of environmentally friendly waste, where bietanol contains $35 \%$ oxygen, so that it can streamline combustion and reduce greenhouse gas emissions, bioethanol is easily decomposed and safe because it does not pollute the water.$^{1}$ According to Iris Mustika Sari et al, 2008: 26 "Biethanol can be made from raw materials in the form of sugar cane, tapioca, sorghum, wheat, rice and lignocellulosic materials such as wood and agricultural waste". ${ }^{2}$
Biotenol is ethanol made from biomass which contains components of starch or cellulose ${ }^{2}$. Bioethanol is obtained from fermentation of materials containing sugar. The core stage of bioethanol production is fermentation of sugar, both in the form of glucose, sucrose, and fructose by yeast (yeast), especially Saccharomyces sp. or Zymomonas mobilis bacteria. In this process, sugar will be converted to ethanol and carbon dioxide gas $^{3}$.

Cocoa (Theobroma cacao) is a plant that can grow in tropical areas. Cocoa fruits are oval shaped in green and red. When ripe cocoa fruit will turn yellow. Mature cacao fruit will be taken by the seeds to be used as the main ingredient in making cocoa powder (chocolate). Cocoa powder is an ingredient in making cakes, ice cream, snacks, milk, and others. The character of chocolate flavor is savory, with a distinctive aroma that is liked by many people, especially children and adolescents. However, this agricultural waste is the skin from cocoa fruit which is underutilized by the community. According to research that has been 
done previously this waste of unused cocoa peel can be used as an ingredient in making biethanol, because cocoa pods contain $39.45 \%$ crude fiber and $3.92 \%$ glucose, with the presence of crude fiber, cocoa can be used as raw materials for bioethanol production $^{4}$. Therefore, to increase the added value of cacao fruit peel waste, the waste can be used as a material for making biethanol to be an alternative fuel.

Making bioethanol using fiber must be done by hydrolysis process first. This hydrolysis process can be carried out in two ways: enzymatically and chemically. This chemical hydrolysis process can be carried out by adding concentrated acid for example $\mathrm{HCl}$ and $\mathrm{H} 2 \mathrm{SO} 4$ and the enzymatic hydrolysis process can be carried out by adding cellulase enzymes using Trichoderma viride mold. ${ }^{5}$

This mold can break down cellulose into glucose which will be broken down into glucose which will be used for fermentation. The process of hydrolysis using mold Trichoderma virideini is more profitable than using concentrated acid because it does not produce inhibitor ingredients, which can interfere with the growth of yeast, other than that the sugar produced is sugar that can be easily converted by yeast while hydrolysis with concentrated acid produces inhibitor ingredients which can inhibit fermentation ${ }^{6}$. Therefore the author is very interested in conducting research on "Making Bioethanol from Cocoa Fruit Skin Waste by Hydrolysis Process Using Trichoderma viride mold"

\section{Experimental}

\subsection{Tools and Materials}

The tools used are pounder, centrifuge, vortex, autoclave, sample container, bottle, hose, supernatant place, drop pipette, filter paper, $\mathrm{pH}$ meter, beaker, test tube, analytical balance, aluminum foil, test tube, spoon, erlenmeyer, tube rack, volume pipette, suction ball, micro pipette, volumetric flask, gauze, cotton, measuring cup, bunsen, stirring rod and steel wire.

The material used is waste from cocoa peel obtained from cocoa farmers from Taluk Kuantan, Trichoderma viride mushroom, acetic acid, Naacetate, Saccaromyecescereviseae yeast, PDA agar (Potato Dextrosa Agar), urea, activated charcoal, 80 tween and distilled water.

\subsection{Research Procedure}

\subsubsection{Sample Preparation}

The ripe cacao fruit skin waste is taken, scraped with a spoon and the inside of the white skin is taken. Then the part of the kakaoyang fruit peel has been taken dried in the sun. After being dried it is pounded with wood mortar and sifted with a tepun sie

\subsection{2.. Hydrolysis process}

a. Breeding fungi Trichoderma viride

Trichoderma Viride mold from pure culture was rejuvenated in PDA medium. Trichoderma viride culture was carried out with an aseptic ose needle into the PDA tilted and incubated for 7 days at room temperature. Trichoderma viride fungus removal was carried out by taking a tube of pure culture of Trichodeerma viride aged 7 days on a PDA tilted and then suspended with $10 \mathrm{ml}$ sterile distilled water into a test tube and distorted ${ }^{7}$. b. Hydrolysis

Samples of 25 grams of fruit peel waste were put into $250 \mathrm{ml}$ Erlenmeyer and added $100 \mathrm{ml}$ of distilled water. In the solution $50 \mathrm{ml}$ of acetate buffer $0.2 \mathrm{M} \mathrm{pH} 5$ and urea as much as 37.5 grams are added. Then it was sterilized in an autoclave at $1210 \mathrm{C}$ for 15 minutes and cooled. Then the suspended Trichoderma virideyang mold was put into the sample and incubated for 6 days.$^{3}$

Before extraction, tween 80 was added as much as $0.1 \%$. Liquid extraction is carried out using filters and centrifuges at $5000 \mathrm{rpm}$ for 1 hour. The resulting supernatant is then sterilized and bleached using $2 \%$ activated charcoal. Then the supernatant that has been produced is taken for use in the fermentation process. Before the supernatant is used for fermentation processes, treatment is tested first using a $\mathrm{pH}$ meter. The aim is to make the $\mathrm{pH}$ suitable for the growth of Saccaromyeses cereviseae yeast, the $\mathrm{pH}$ suitable for the growth of this yeast is $\mathrm{pH} 4.5$. If the $\mathrm{pH}$ of the supernatant obtained from 3 is added to the base of the drop drop $\mathrm{NaOH}$ until the desired $\mathrm{pH}$ is obtained and if the supernatant $\mathrm{pH}$ produced above 6 then added with drop drops acetic acid until the desired $\mathrm{pH}$ is obtained.

3. Fermentation

The supernatant that has an acidic $\mathrm{pH}$ is put into the bottle. Then the sample was added with Saccharomyces cereviseae yeast with yeast weight varied, namely 2, 4 and 6 grams. The fermentation time variations used for each sample volume are 1, $3,5,7$ and 9 days.

1. Determination of Ethanol Levels

The results of ethanol fementation were tested using a vinometer tool for determining the level.

\section{Results and Discussion}

\subsection{Result}

From the research that has been done, obtained ethanol levels from cocoa peel waste by comparing the fermentation time and yeast variation from the hydrolilis process using Trichoderma viride mold can be seen in Table

Table1. Determination of Ethanol Levels is produced at 3 days fermentation and 6 grams yeast content 


\begin{tabular}{|c|l|c|c|c|}
\hline \multirow{2}{*}{$\begin{array}{c}\text { Yeast } \\
\text { Yeay }\end{array}$} & \multicolumn{4}{|c|}{ Level Etanol (\%) } \\
\cline { 2 - 5 } & 1 & 3 & 5 & \multicolumn{1}{c|}{7} \\
\hline 2 & 5,33 & 7,17 & 4,83 & 3,17 \\
\hline 4 & 7,67 & 8,83 & 7,33 & 3,33 \\
\hline 6 & 10,67 & 12 & 7,67 & 6 \\
\hline 8 & 6,17 & 7,17 & 5,5 & 3,17 \\
\hline
\end{tabular}

For more details can be seen in the following graph:

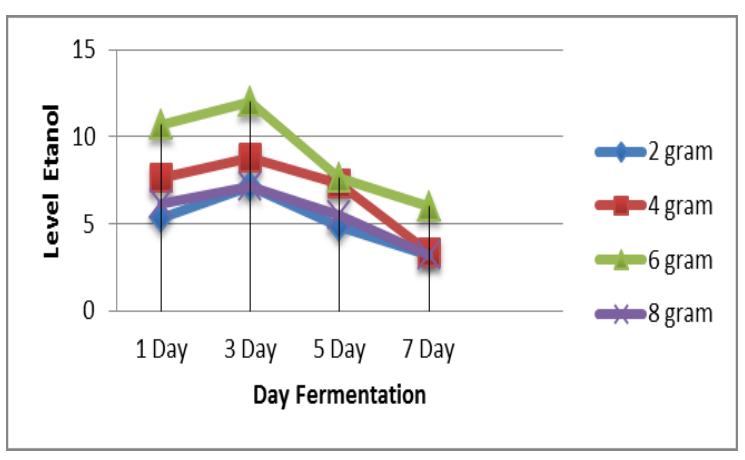

Figure 1. Graph of Ethanol Levels with Comparison of Yeast and Fermentation Time

The ethanol production process is carried out with fermentation conditions at room temperature and the bottle is given a pipette to drain $\mathrm{CO} 2$ gas because the longer the fermentation time will increase the $\mathrm{CO} 2$ gas produced. The presence of $\mathrm{CO} 2$ gas can inhibit Saccharomyce cerevisiae itself so that the level of ethanol decreases. According to Datar in Azizah with the presence of $\mathrm{CO} 2$ gas during the fermentation process the growth of saccharomyce cerevisia will stop even if saccharomyce cerevisiae is still alive, then it will produce alcohol again if $\mathrm{CO} 2$ is removed

The average ethanol content of cacao fruit peel waste produced during fermentation by saccharomyces cerevisiae yeast using Trichoderma viride mold on days $1,3,5$, and 7 with a 2 yeast weight was $5.33 \%, 7.17 \%, 4.83 \%$ and $3.17 \%$. With 4 grams of yeast using the same day variation is $7.76 \%, 8.83 \%, 7.33 \%$, and $3.33 \%$. At 6 grams yeast with the same day variation is $10.67 \%, 12 \%$, $7.67 \%$ and $6 \%$ while in the 8 gram yeast with the same day variation is $6.17 \%, 7.17 \%, 5,5 \%$ and $3.17 \%$. The table shows that the highest ethanol content for all yeast content variations occurred on the 3 rd day where yeast was 2 grams at $7.17 \%, 4$ grams at $8.83 \%, 6$ grams at $12 \%$ and 8 grams at $7.17 \%$. According to Mulyono in Sari, this can happen because on that day the yeast has an increase in the number of cells followed by an increase in the enzyme produced to break down glucose into ethanol. ${ }^{8}$

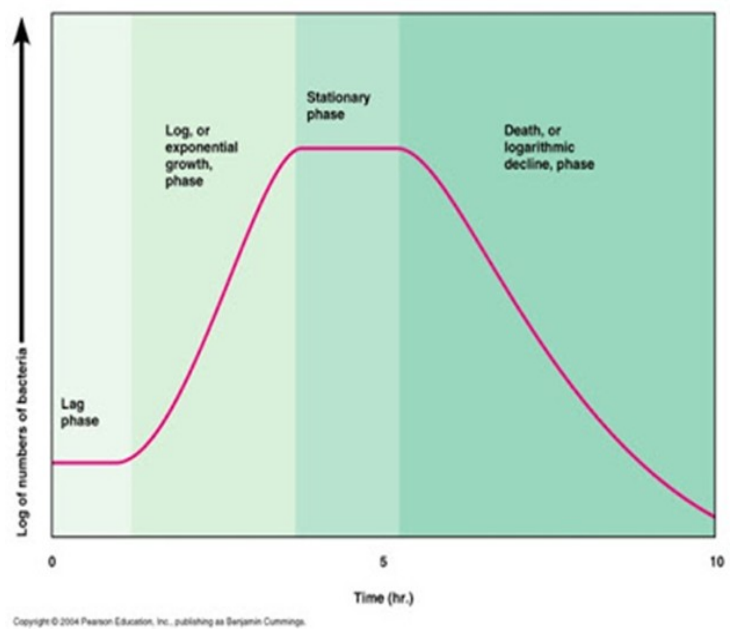

Figure 2. Bacterial Growth Curve

According to Azizah the growth of Saccharomyces cerevisiae yeast can be described by the bacterial growth curve in the picture above which shows each growth phase. Where in this study yeast growth can be seen from graph 2, for example the addition of 2 grams of yeast. On the first day there was still a small amount of ethanol which was $5.33 \%$. This happens because on that day the yeast experiences a lag phase, where in this phase the yeast still adjusts to the environment. The duration of this phase in bacteria varies greatly, depending on the composition of the media, $\mathrm{pH}$, temperature, aeration, the number of cells in the initial inoculum and the physiological properties of microorganisms in the previous media. On the 3rd day the ethanol content produced increased by $7.17 \%$. This increase in the amount of ethanol is called the exponential phase, where in this phase the yeast experiences very fast cell division followed by the maximum population of cells.

Then the yeast undergoes a stationary phase that shows the bacteria are no longer working optimally. The stationary phase occurs because the availability of glucose and nutrients in the fermentation medium has begun to decrease so that it is not comparable to the large number of bacteria that continue to multiply during the fermentation process, so there is a possibility of more yeast many use these nutrients to survive rather than break down sugar into alcohol. This stationary phase can be seen by decreasing ethanol levels to $4.83 \%$ on day ${ }^{5}$.

After the stationary phase, the resulting ethanol concentration has dropped and tends to be constant. At this stage the yeast has experienced a phase of death which is marked by an increase in 
the rate of death that exceeds the rate of growth, so that overall bacterial population decline. Where at this stage the ethanol content produced is $3.17 \%$ on the 7th day. Sari in Azizah stated that the optimal fermentation time for the process of making bioethanol is 3 days, if the fermentation is done more than 3 days, the alcohol content can be reduced, the decrease in alcohol content is caused by alcohol being converted to other compounds such as esters. ${ }^{4}$ The duration of fermentation is influenced by several factors including nutrition, temperature, $\mathrm{pH}$ and oxygen. The temperature used in this fementation process is a room temperature of $30^{\circ} \mathrm{C}$. According to Volk in Apriwinda stated that the optimal temperature of yeast growth is between $25^{\circ} \mathrm{C}$ and $30^{\circ} \mathrm{C}$. The increase in temperature will reduce yeast resistance to alcohol produced and will increase the formation of acetic acid which is toxic.

Whereas for the use of yeast content variations in table 1 shows that the addition of yeast content causes the resulting ethanol content to increase. For example, it can be seen from the 3rd day, the addition of yeast weighing 2 grams produces ethanol levels of $7.17 \%$ and rises to $8.83 \%$ on the addition of 4 grams of yeast, continues to rise to $12 \%$ with the addition of 6 grams of yeast and will experience decrease with the addition of 8 grams of yeast by $7.17 \%$. Harimbi stated that this was because the amount of available nutrition was not comparable to the number of Saccaromyces cerevisiae which was higher, so Saccharomyces cereviceae lacked food which resulted in decreased performance of Saccharomyces cereviceae and decreased levels of bioethanol produced. So to optimize the addition of yeast weight in the fermentation process is 6 grams. The hydrolysis process using Trichoderma viride mold is better than the hydrolysis process that uses acid. Because it can produce high ethanol levels, this happens because the sugar produced in the process of hydrolysis using mold Trichoderma viride can easily be changed by yeast while the process of hydrolysis using acid produces inhibitor materials that can interfere with fermentation. This can be evidenced by the level of ethanol produced from this study is greater than previous studies that use the process of acid hydrolysis ${ }^{9}$. Where the ethanol content produced from the study is $10.90 \%$ while in this study the resulting ethanol content is $12 \%$.

\section{Statistical Analysis ${ }^{10}$}

The results of the two-way ANOVA calculation analysis of ethanol content produced using variations in yeast content and fermentation time can be seen from the following table:
Table 2. Calculation of Two-Way Anova Effect of Addition of Yeast Level

\begin{tabular}{l|c|c|c|c|c}
\hline $\begin{array}{l}\text { Amount } \\
\text { of } \\
\text { variation }\end{array}$ & $\mathrm{dk}$ & $\mathrm{Jk}$ & $\mathrm{Rk}$ & $\begin{array}{c}\mathrm{F} \\
\text { count }\end{array}$ & $\begin{array}{c}\mathrm{F} \\
\mathrm{tabl} \\
\mathrm{e}\end{array}$ \\
\hline $\begin{array}{l}\text { Yeast } \\
\text { Level }\end{array}$ & 3 & $\begin{array}{l}111,80 \\
13,16\end{array}$ & $\begin{array}{l}37,26 \\
0,41\end{array}$ & 90,97 & 2.90 \\
\hline
\end{tabular}

The results of the two-way ANOVA test showed that the addition of yeast content, ie yeast levels of 2 grams, 4 grams, 6 grams and 8 grams showed a significant difference with $\mathrm{F}$ count $=90.667$ while $\mathrm{F}$ table at a significance level of $5 \%=2.90$. Based on these data, the calculated $\mathrm{F}$ value is greater than F table (90.667> 2.90), Ha is accepted means that the variation of yeast content affects the level of ethanol produced.

Table 3. Two-way ANOVA Calculation of the Effect of Fermentation Time

\begin{tabular}{l|c|c|c|c|c}
\hline $\begin{array}{l}\text { Amount } \\
\text { of } \\
\text { variation }\end{array}$ & $\mathrm{dk}$ & $\mathrm{Jk}$ & $\mathrm{Rk}$ & $\begin{array}{c}\mathrm{F} \\
\text { count }\end{array}$ & $\begin{array}{c}\mathrm{F} \\
\mathrm{tabl} \\
\mathrm{e}\end{array}$ \\
\hline $\begin{array}{l}\text { Day } \\
\text { fermenta } \\
\text { tion }\end{array}$ & 32 & $\begin{array}{l}274,91 \\
13,16\end{array}$ & $\begin{array}{l}48,57 \\
0,41\end{array}$ & 118,18 & 2,90 \\
\hline
\end{tabular}

For the variation of ethanol fermentation time produced showed a significant difference with $\mathrm{F}$ count $=118.187$ while the $\mathrm{F}$ table at a significance level of $5 \%=2.90$ this means that the calculated $\mathrm{F}$ is greater than $\mathrm{F}$ table $(118.187>2.90) \mathrm{Ha}$ is accepted. Based on these data the variation of fermentation time affects the level of ethanol produced

Table 4. Calculation of Two-Way ANOVA Interaction Between Addition of Yeast Level and Fermantation Time

\begin{tabular}{|c|c|c|c|c|c|}
\hline $\begin{array}{l}\text { Amount of } \\
\text { variation }\end{array}$ & $\mathrm{dk}$ & $\mathrm{Jk}$ & $\mathrm{Rk}$ & $\begin{array}{c}\mathrm{F} \\
\text { count }\end{array}$ & $\begin{array}{c}\mathrm{F} \\
\text { table }\end{array}$ \\
\hline $\begin{array}{l}\text { Interaction } \\
\text { Between } \\
\text { Addition of } \\
\text { Yeast Level } \\
\text { and } \\
\text { Fermantation } \\
\text { Time }\end{array}$ & $\begin{array}{c}9 \\
32\end{array}$ & $\begin{array}{c}17 \\
38 \\
13,1 \\
6\end{array}$ & $\begin{array}{l}1,93 \\
0,41\end{array}$ & 4,69 & 2,19 \\
\hline
\end{tabular}

Whereas for the interaction between yeast levels and fermentation time also showed a real difference with the $F$ value calculated $=4.698$ while the $F$ table at a significance level of $5 \%=2.19$. This 
means that the calculated $\mathrm{F}$ is greater than $\mathrm{F}$ table $(4,968>2,19) \mathrm{Ha}$ is accepted. Based on these data, the interaction between yeast variability and fermentation time variation affects the level of ethanol produced.

\subsection{Conclusion}

Preparation of bioethanol from cacao fruit peel waste by hydrolysis process using Trichoderma viride mold, obtained the highest ethanol content for all weight variations of yeast occurs on the $3 \mathrm{rd}$ day where yeast 2 grams is $7.17 \%, 4$ grams is $8.83 \%, 6$ grams by $12 \%$ and 8 grams by $7.17 \%$

Optimizing the use of optimal variation in yeast weight of ethanol content resulting in the addition of 6 grams of yeast on day 3 with an ethanol content of $12 \%$

The results of the two-way ANOVA calculation analysis showed that the addition of yeast content and fermentation time variation and the interaction of the two treatments had a significant effect on the resulting ethanol content where the $\mathrm{F}$ value calculated from each variation was greater than $\mathrm{F}$ table. This means that Ha is accepted.

\section{Acknowledgement}

In completing this research the author realizes so much help from various parties who have given a helping hand and generosity to the author. In addition, on this occasion the author also wishes to express respectfully the profound gratitude to $\mathrm{Mr}$. Ir. Mokhamad Irfan, M.Sc. as head of the State Islamic University Sultan Syarif Kasim Riau Pathology, Entomoly and Microbiology laboratory along with an assistant who has the pleasure to accept the author to conduct this research and Lecturer in chemical education at State Islamic University Sultan Syarif Kasim Riau who has provided motivation and guidance for the smooth running of this research

\section{Reference}

1. Pratiwi, Eka P, M. Yamin, and Luluk Endahwati. 2010. Utilization of Chocolate Fruit Skin Waste as Bioethanol. ISN 16934392. Hal: 1-7

2. Sari, Iris Mustika Noverita and Yulneriwarni, Utilization of Rice and Alang Straws in Ethanol Fermentation Using Trichoderma viride and Khamir Saccharomyces cereviseae, National University, Jakatra, 2008, p. 55

3. Azizah, N., A. N. Albaari and S. Mulyani. 2012, Effect of Long Fermentation on Alcohol, $\mathrm{pH}$, and Gas Production Levels on Bioethanol
Fermentation Process from Whey with Pineapple Skin Substitution. Journal of Food Technology Applications, Vol. 1 No.2,

4. S. Mack. "Desperate Optimism." M.A. thesis, University of Calgary, Canada, 2000.

5. Hermiati, Euis, Hermiati, Djumali Mangunwidjaja, Titi Candra Sunarti, Ono Suparnodan Bambang Prasetya, Utilization of Lignocellulosic Sugar Cane Biomass for Bioethanol Production. Agricultural Research and Development Journal, 29 (4), 2010

6. Hambali, Erliza, Siti Mujdalifah, Armansyah Halomoan. Tambunan, Abdul Waries Pattiwiri and Roy Hendroko 2008. Bioenergy technology. Jakarta: Agro Media Library

7. Arnata, I Wayan. 2009. Thesis AlternativeDevelopment of Bioethanol Bioprocessing Technology from Cassava Using Trichoderma viride, Aspergillus niger and Saccharomyces cereviseae. Bogor: IPB.

8. Prihandana, Rama Kartika Noerwijan, Praptiningsih Gamawati Adinurani, Dwi Setyaningsih, Sigit Setiadi and Roy Hendroko. 2007. Bioethanol of Cassava for Future Fuels. Jakarta: Agro Media Library, Jakarta.

9. Apriwinda.2013, Thesis Study of the Fermentation of Nira Stems of Sweet Sorghum (Sorghum Bicolor (LMoench) for Ethanol Production, Makassar: Hasanuddin University

10. Hartono, 2006. Statistics for Research. Yogyakarta: Institute of Philosophy Studies, Society, Education and Women 